\title{
Quintamillesimal Series of Attenuation
}

National Cancer Institute

\section{Source}

National Cancer Institute. Quintamillesimal Series of Attenuation. NCI Thesaurus. Code C88108.

Preparation of a homeopathic substance with a ratio of one part original material to 50,000 parts of carrier or solvent, traditionally this is lactose, water or ethanol. 